\title{
EVALUATION OF THE CHEMICAL COMPOSITION OF AJUGA CHAMAEPITYS (L.) SCHREB. FROM THE SPONTANEOUS FLORA OF ROMANIA
}

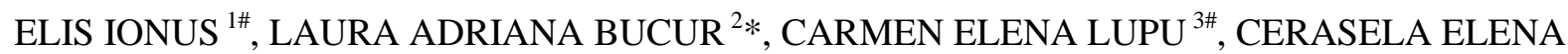 \\ GÎRD $^{1}$ \\ I "Carol Davila" University of Medicine and Pharmacy, Faculty of Pharmacy, Department of Pharmacognosy, Phytochemistry \\ and Phytotherapy, 6 Traian Vuia Street, District 2, 020956, Bucharest, Romania \\ 2 "Ovidius" University of Constanţa, Faculty of Pharmacy, Department of Pharmacognosy, Phytochemistry and Phytotherapy, \\ 6 Căpitan Aviator Al. Șerbănescu Street, Campus, Corp C, Constanţa, Romania \\ 3 "Ovidius" University of Constanţa, Faculty of Pharmacy, Department of Mathematics and Informatics, 6 Căpitan Aviator Al. \\ Șerbănescu Street, Campus, Corp C, Constanţa, Romania
}

*corresponding author: adrianabucur@yahoo.com

${ }^{*}$ Authors with equal contribution

Manuscript received: November 2020

\begin{abstract}
Ajuga chamaepitys (L.) Schreb., traditionally named yellow bugle, is a perennial species that is part of the Dobrogea region, Romania, spontaneous flora, associated in traditional phytotherapy. The aim of this study was to determine the qualitative and quantitative chemical composition of different types of plant organs (aerial parts, leaves, flowers, stems and roots), as well as the optimal harvesting interval. Thus, higher levels in the flavones, phenolic acids and total polyphenols content were recorded in the plant's flowers, our analysis yielding $7.1501 \mathrm{~g}$ flavonoid content (expressed as rutin equivalents)/100 $\mathrm{g}$ dry herbal product, $1.5751 \mathrm{~g}$ phenolic acids content (expressed as chlorogenic acid equivalents)/100 g dry herbal product, respectively $5.706 \mathrm{~g}$ total phenolic content (expressed as tannic acid equivalents)/100 $\mathrm{g}$ dry herbal product.
\end{abstract}

\section{Rezumat}

Ajuga chamaepitys (L.) Schreb., tămâiță de câmp, este o specie perenă întâlnită în flora spontană din regiunea Dobrogei, România, asociată în fitoterapia tradițională. Scopul studiului a fost determinarea compoziției chimice calitative și cantitative a diferitelor tipuri de organe vegetale (părți aeriene, frunze, flori, tulpini și rădăcini), precum și a intervalului optim de recoltare al acestora. Conţinutul maxim în flavone, acizi fenolici şi polifenoli totali a fost înregistrat în probele de flori, obţinându-se 7,1501 g flavone (exprimați în echivalenți de rutin)/100 g produs vegetal uscat, 1,5751 g acizi fenolici (exprimați în echivalenți de acid clorogenic)/100 g produs vegetal uscat, respectiv 5,706 g polifenoli totali (exprimaţi în echivalenți de acid tanic)/100 g produs vegetal uscat.

Keywords: Ajuga chamaepitys (L.) Schreb., phytochemical screening, phenolic acids, rutin, polyphenols

\section{Introduction}

Ajuga chamaepitys (L.) Schreb. taxonomically is a species that belongs to the family Lamiaceae, subfamily Ajugoideae, genus Ajuga [4]. The plants from the genus Ajuga are widespread in the spontaneous flora of Europe, Asia, Australia, North Africa and North America, and comprise about 300 species and countless naturalized subspecies around the globe [10]. Ajuga chamaepitys (L.) Schreb. is a small, annual or biennial herbaceous plant that blooms in the summer from May to August, and presents a thin, quadrangular, hairy, 10 - $30 \mathrm{~cm}$ long stem, while its root is rhizomeshaped and its leaves are $1-4 \mathrm{~cm}$ long, tripartite and hairy, with flowers which are up to $15 \mathrm{~mm}$ long. The corolla ranges from yellow to pale red, it is $10-15 \mathrm{~mm}$ long, and has two lips, whereas its fruits appearance is a tetranucule and the whole plant emits a pine scent when crushed $[4,22,25]$.

Traditionally, the Ajuga species, including Ajuga chamaepitys (L.) Schreb., were used as a diuretic, tonic, emmenagogue, as well as for wound healing (crushed leaves were applied to wounds), for the treatment of scorpion and snake bites, for the treatment of haemorrhoids, stomach pain, jaundice, inflammatory diseases such as gout, as well as in common colds $[9,24]$. Various extracts of this species have been investigated and their antimicrobial [12, 23, 24], antioxidant [5, 9, 12, 23], antiviral [16], antinociceptive [11] and cytotoxic [16, 22, 25] properties with multiple benefits for the human body have been reported. Regarding the chemical composition, several studies have been conducted on extracts with different solvents which have shown the presence of flavonoids [12], polyphenols [5, 12], iridoids [25], neoclerodane di- 
terpenes [1, 2, 8, 22], phytoecdisterones [19] and volatile components $[5,6,25,26]$, which explain the plant's uses in traditional medicine.

The aim of our study is to collect preliminary data regarding the chemical composition, which implies determining the content of flavones, polyphenols and phenolic acids in the hydro-alcoholic extract (70\% ethanol v/v) of Ajuga chamaepitys (L.) Schreb. collected in different months of flowering. From our knowledge, this is the first study of this kind carried out on Ajuga chamaepitys (L.) Schreb. from the spontaneous flora of Romania.

\section{Materials and Methods}

Plant material. Ajuga chamaepitys (L.) Schreb. species were collected from the spontaneous flora from the

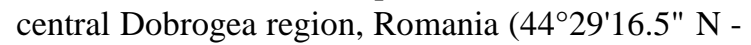
$\left.28^{\circ} 27^{\prime} 09.5^{\prime \prime} \mathrm{E}\right)$ in the morning, in sunny weather. The specimen was identified by Assoc. Prof. Mariana Arcuş from the Pharmaceutical Botany Department, Faculty of Pharmacy, "Ovidius" University of Constanţa, Romania. The harvesting was carried out in each flowering month in 2019 (May, June, July and August), resulting in four batches of analysis (May - sample 1, June - sample 2, July - sample 3 and August - sample 4). Also, six plant organs (flowers, leaves, stems, roots, fruits and aerial parts) were sorted from each batch that were afterwards subjected to the phytochemical study. The harvesting was performed as follows: for aerial parts, resulting in sample $\mathrm{H} 1$ (harvested in May), sample H2 (harvested in June), sample H3 (harvested in July) and sample H4 (harvested in August); for leaves, resulting in sample F1 (May), sample F2 (June), sample F3 (July) and sample F4 (August); for flowers, resulting in sample FL1 (May), sample FL2 (June), sample FL3 (July) and sample FL4 (August); for stems, resulting in sample C1 (May), sample C2 (June), sample C3 (July) and sample C4 (August); and for roots, resulting in sample R1 (May), sample R2 (June), sample R3 (July), and sample R4 (August). We decided to exclude the fruits, because they were in a very small amount. The plant materials were dried in the shade, at room temperature, in the Pharmacognosy laboratory of the Faculty of Pharmacy, "Ovidius" University of Constanţa, Romania.

Reagents and solvents. All chemicals (aluminium chloride, chlorogenic acid, ethanol, hydrochloric acid, rutin, sodium hydroxide, sodium nitrite and tannic acid) were purchased from Sigma-Aldrich, Germany. Obtaining the extractive solutions

Preparation of samples for spectrophotometric assays $1 \mathrm{~g}$ of dried sample (from each batch) was heated with $25 \mathrm{~mL} \mathrm{70 \%} \mathrm{ethanol} \mathrm{(v/v)} \mathrm{on} \mathrm{a} \mathrm{reflux} \mathrm{condenser} \mathrm{for} 30$ min. After cooling, the solutions were filtered in a $25 \mathrm{~mL}$ volumetric flask and filled to the mark with the same solvent. The extracts were stored at $4{ }^{\circ} \mathrm{C}$ until analysis.
Spectrophotometric assays. The flavonoids content (FC) was determined based on the chelating reaction with aluminium chloride [14]. The phenolic acids content (PAC) was assessed based on the formation of oxymes in the presence of sodium nitrite/hydrochloric acid and sodium hydroxide [14]. The total phenolic content (TPC) was evaluated based on the capacity to reduce molybdenic compounds (VI) [14, 18]. All the spectrophotometric determinations were performed using a UV-VIS Jasco V-530 spectrophotometer (Jasco, Japan). The following calibration curves were used to determine the active compounds content: rutin (linearity range: $5.0-35.0 \mu \mathrm{g} / \mathrm{mL}, \mathrm{r}=0.9998$, $\mathrm{n}=11$ ), chlorogenic acid (linearity range: $11.3-52.7$ $\mu \mathrm{g} / \mathrm{mL}, \mathrm{r}=0.9998, \mathrm{n}=6$ ) and tannic acid (linearity range: 2.0 - $12.0 \mu \mathrm{g} / \mathrm{mL}, \mathrm{r}=0.9990, \mathrm{n}=10$ ).

Statistical analysis. The statistical package SPSS 20.0 (SPSS Inc., Chicago, USA) was used for the statistical processing and data evaluation. All of the determinations were made in triplicate, and the means and standard deviations were calculated.

Analysis of variance (ANOVA) was performed to assess the effect of time of harvest. The post hoc comparisons of mean quantities were made using the least significant difference (LSD) post-hoc test. Differences were considered significant when the $\mathrm{p}<$ 0.05 . The time of harvest (month) was considered a fixed factor.

\section{Results and Discussion}

Meteorological conditions influence the amount of active principles, therefore we mention that the meteorological circumstances of winter (2018 - 2019) were milder in Dobrogea region from Romania, the precipitations were lower, resulting in a deficit of moisture in the soil in March 2019 (pedological drought was moderate to strong, according to the National Meteorological Administration) [27], and the average air temperature was higher than in other years.

The chemical composition depends on the meteorological (pedo-climatic) conditions for each month in which the harvesting was done. However, these observations overlap with the accumulation dynamics of the compounds, which vary depending on the month in which the plant was harvested.

The results obtained from ANOVA have indicated significant differences $(p<0.05)$ between analysed herbal products and the time of harvest for FC regarding the aerial parts $(\mathrm{F}=16.539, \mathrm{p}<0.001)$ and leaves $\mathrm{F}=8.451, \mathrm{p}=0.002)$, for PAC for roots $(\mathrm{F}=$ $62.545, \mathrm{p}<0.000)$ and for TPC for leaves $(\mathrm{F}=14.308$, $\mathrm{p}=0.001)$ and flowers $(\mathrm{F}=10.943, \mathrm{p}=0.003)$.

The results of the quantitative and LSD post hoc test analysis of flavonoids, phenolic acids and total polyphenols are shown in Table I. 
Table I

Results of the spectrophotometric determinations

\begin{tabular}{|c|c|c|c|c|}
\hline Sample & Time of harvest & $\begin{array}{c}\mathrm{g} \% \mathrm{FC} \text { expressed as } \\
\text { rutin }\end{array}$ & $\begin{array}{l}\text { g\% PAC expressed as } \\
\text { chlorogenic acid }\end{array}$ & $\begin{array}{c}\text { g\% TPC expressed as } \\
\text { tannic acid }\end{array}$ \\
\hline \multirow{4}{*}{ aerial parts } & H1 & $1.2423 \pm 0.2751^{\mathrm{b}, \mathrm{c}, \mathrm{d}}$ & $1.0488 \pm 0.2891^{\mathrm{c}, \mathrm{d}}$ & $2.5807 \pm 0.3483^{b, c}$ \\
\hline & $\mathrm{H} 2$ & $0.7979 \pm 0.2161^{\mathrm{a}, \mathrm{c}, \mathrm{d}}$ & $0.897 \pm 0.1489$ & $2.0893 \pm 0.1319^{\mathrm{a}}$ \\
\hline & $\mathrm{H} 3$ & $0.4799 \pm 0.14^{\mathrm{a}, \mathrm{b}}$ & $0.683 \pm 0.0702^{\mathrm{a}}$ & $1.8201 \pm 0.1038^{\mathrm{a}}$ \\
\hline & $\mathrm{H} 4$ & $0.4704 \pm 0.1324^{\mathrm{a}, \mathrm{b}}$ & $0.6621 \pm 0.1084^{\mathrm{a}}$ & $2.2087 \pm 0.2007$ \\
\hline \multirow{4}{*}{ leaves } & $\mathrm{F} 1$ & $1.2854 \pm 0.2888^{\mathrm{b}, \mathrm{c}, \mathrm{d}}$ & $1.0287 \pm 0.3429^{\mathrm{a}, \mathrm{b}, \mathrm{c}}$ & $2.1872 \pm 0.1094^{\mathrm{a}, \mathrm{b}, \mathrm{c}}$ \\
\hline & F2 & $0.7341 \pm 0.2124^{\mathrm{a}}$ & $0.6706 \pm 0.1051^{\mathrm{a}}$ & $1.8055 \pm 0.2949^{\mathrm{a}, \mathrm{c}}$ \\
\hline & F3 & $0.5635 \pm 0.2043^{\mathrm{a}}$ & $0.6251 \pm 0.1761^{\mathrm{a}}$ & $1.3105 \pm 0.0789^{\mathrm{a}, \mathrm{b}}$ \\
\hline & $\mathrm{F} 4$ & $0.6244 \pm 0.2144^{\mathrm{a}}$ & $0.6612 \pm 0.1394^{\mathrm{a}}$ & $1.5978 \pm 0.0942^{\mathrm{a}}$ \\
\hline \multirow{4}{*}{ flowers } & FL1 & $7.1501 \pm 2.456^{\mathrm{d}}$ & $1.5751 \pm 0.8046$ & $5.706 \pm 0.8992^{\mathrm{b}, \mathrm{c}, \mathrm{d}}$ \\
\hline & FL2 & $5.3265 \pm 2.5396$ & $1.1345 \pm 0.4287$ & $3.349 \pm 0.6728^{\mathrm{a}}$ \\
\hline & FL3 & $4.8639 \pm 2.2339$ & $1.1694 \pm 0.4722$ & $3.5503 \pm 0.2324^{\mathrm{a}}$ \\
\hline & FL4 & $4.0542 \pm 1.7491^{\mathrm{a}}$ & $1.1056 \pm 0.3576$ & $2.8384 \pm 0.3171^{\mathrm{a}}$ \\
\hline \multirow{4}{*}{ stems } & $\mathrm{C} 1$ & $0.4072 \pm 0.1656$ & $0.5071 \pm 0.0464$ & $1.2148 \pm 0.146$ \\
\hline & $\mathrm{C} 2$ & $0.3799 \pm 0.1963$ & $0.4764 \pm 0.0476$ & $1.2548 \pm 0.1925$ \\
\hline & $\mathrm{C} 3$ & $0.2241 \pm 0.0356$ & $0.5548 \pm 0.0975$ & $1.5792 \pm 0.2819$ \\
\hline & $\mathrm{C} 4$ & $0.2628 \pm 0.0541$ & $0.4673 \pm 0.0429$ & $1.2888 \pm 0.187$ \\
\hline \multirow{4}{*}{ roots } & R1 & - & $0.6682 \pm 0.0585^{b, c, d}$ & $1.2822 \pm 0.0951$ \\
\hline & $\mathrm{R} 2$ & - & $0.4201 \pm 0.0196^{\mathrm{a}, \mathrm{c}, \mathrm{d}}$ & $1.2705 \pm 0.1332$ \\
\hline & R3 & - & $0.2707 \pm 0.0209^{\mathrm{a}, \mathrm{b}}$ & $1.1619 \pm 0.2538$ \\
\hline & R4 & - & $0.2673 \pm 0.0735^{\mathrm{a}, \mathrm{b}}$ & $1.0108 \pm 0.2742$ \\
\hline
\end{tabular}

${ }^{*}$ Notes: (1) Values in the same column followed by different superscript lower-case letters show significant difference between time of harvest for each compound based on LSD post-hoc test at $\mathrm{p}<0.05$; (2) Results are presented as the mean \pm SD (standard deviation) $(n=3$ ) H1, H2, H3 and H4 (aerial parts samples from May, June, July and August); F1, F2, F3 and F4 (leaf samples from May, June, July and August); FL1, FL2, FL3 and FL4 (flower samples from May, June, July and August); C1, C2, C3 and C4 (stem samples from May, June, July and August); R1, R2, R3 and R4 (root samples from May, June, July and August); FC = flavonoids content; PAC = phenolic acids content; TPC $=$ total phenolic content

\section{Quantitative analysis of flavonoids $(F C)$}

The application of the LSD post hoc test has shown that the herbal products which were collected from sample 1 (sample FL1) statistically contain significantly higher $(\mathrm{p}<0.05)$ amounts flavonoids content $(\mathrm{FC})$ than herbal products from other samples. On the other hand, FC were not detected in roots (Figure 1).

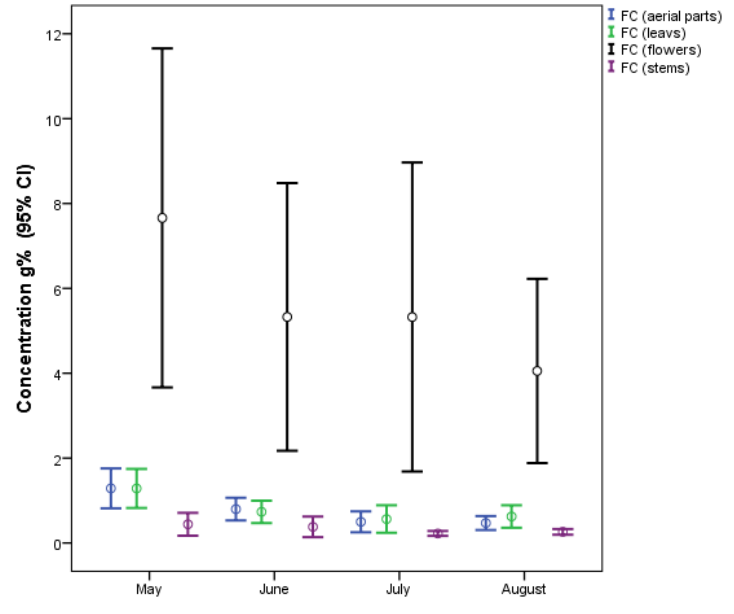

Figure 1.

Flavonoids content (mean) depending on the harvest period, 95\% CI (confidence interval)

A comparison between our results and the scientific literature is difficult to perform, because the phytochemical studies on Ajuga chamaepitys (L.) Schreb. are few, using different obtaining methods for the extracts and also different solvents. However, we mention that in the ethanolic flowers extract from performed on another Ajuga species (e.g. Ajuga reptans L. collected from the spontaneous flora from the Northern region of the country), $13.75 \pm 0.31$ rutin $\mathrm{mg} / \mathrm{g}$ was obtained [21], which represents a smaller amount compared to that we have obtained in Ajuga chamaepitys (L.) Schreb., namely 71.50 rutin $\mathrm{mg} / \mathrm{g} \mathrm{dw}$ (dry weight - dry herbal product).

Jakovljević et al. performed a phytochemical screening of the aerial parts of Ajuga chamaepitys ssp. chamaepitys, species collected in July 2012 from the Serbian flora, where in the methanolic extract they detected $63.87 \pm$ 0.66 rutin $\mathrm{mg} / \mathrm{g}$, and in the ethyl acetate extract, $91.76 \pm 0.81$ rutin $\mathrm{mg} / \mathrm{g}$ [12], which are higher amounts comparing to our results (sample H1), namely 12.42 rutin $\mathrm{mg} / \mathrm{g} \mathrm{dw}$.

Movahhedin et al. performed an analysis on Ajuga chamaecistus subsp. scoparia using the aerial parts collected from the spontaneous flora of Iran. In the ethanolic extract the content of flavonoids was $11.61 \pm$ 0.16 rutin $\mathrm{mg} / \mathrm{g}$ extract [15], which is near to what we obtained for the aerial parts (sample H1), specifically 12.42 rutin $\mathrm{mg} / \mathrm{g} \mathrm{dw}$.

In the phytochemical screening of the methanolic extracts from the aerial parts of two Ajuga species, Ajuga reptans L. and Ajuga genevensis L., collected from the spontaneous flora of the Republic of Moldova, Ciocârlan et al. obtained the results 0.34 rutin $\mathrm{g} \%$ 
for Ajuga reptans L. and 0.18 rutin $\mathrm{g} \%$ for Ajuga genevensis L. [3], which, compared to our data from the aerial parts (sample H1), namely $1.2423 \pm 0.2751$ $\mathrm{g}$ (expressed as rutin equivalents)/100 $\mathrm{g}$ dry herbal product, shows that our sample contains a higher quantity of flavonoids components.

In a comparative phytochemical analysis performed by Toiu et al. (2019) on extracts from the aerial parts of Ajuga reptans L. and Ajuga genevensis L., collected from the spontaneous flora of Romania from different areas and in different flowering periods, in the case of flavonoids content, the highest value obtained from the Ajuga genevensis L. extract was $15.91 \pm 0.78$ rutin $\mathrm{mg} / \mathrm{g}$ in methanol, respectively $18.72 \pm 0.85$ rutin $\mathrm{mg} / \mathrm{g}$ in ethanol, while for Ajuga reptans L. the results were $11.26 \pm 0.58$ rutin $\mathrm{mg} / \mathrm{g}$ in methanol, respectively $14.05 \pm 0.41 \mathrm{rutin} \mathrm{mg} / \mathrm{g}$ in ethanol [20], results which are approximately similar to that obtained in the H1 sample case of Ajuga chamaepitys (L.) Schreb., namely 12.42 rutin $\mathrm{mg} / \mathrm{g} \mathrm{dw}$.

Quantitative analysis of phenolic acids (PAC)

The results showed (Figure 2) that the highest phenolic acids content (PAC) was recorded in the flowers sample 1 (sample FL1), which yielded the result $1.5751 \pm$ $0.8046 \mathrm{~g}$ (expressed as chlorogenic acid equivalents)/ $100 \mathrm{~g}$ dry herbal product, while, on the other hand, the smallest amount was recorded in the roots (sample R4), namely $0.2673 \pm 0.0735 \mathrm{~g}$ (expressed as chlorogenic acid equivalents)/100 g dry herbal product.

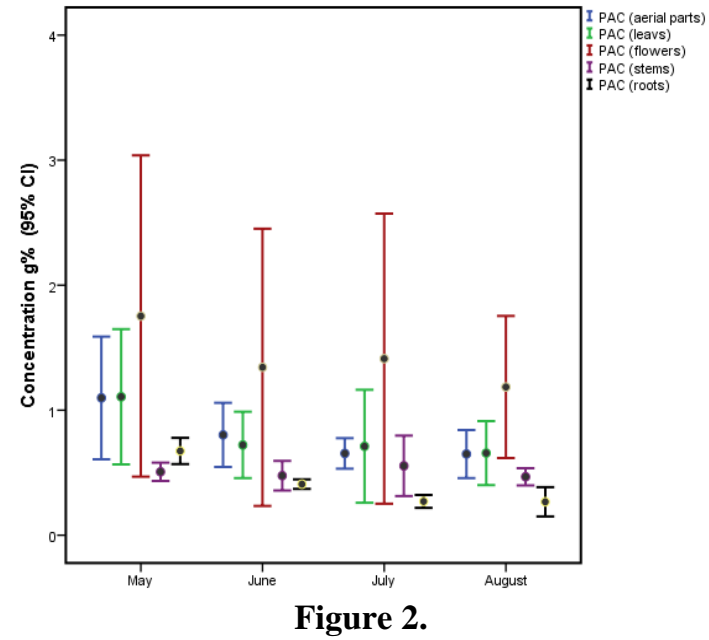

Phenolic acids content (mean) depending on the harvest period, 95\% CI (confidence interval)

No data on the content of phenolic acids was identified in the scientific literature, so a comparison was not possible.

Quantitative analysis of total polyphenols (TPC)

The results showed (Figure 3) that the highest total polyphenols content (TPC) was recorded in the flowers sample 1 (sample FL1), which yielded the result $5.706 \pm$ $0.8992 \mathrm{~g}$ (expressed as tannic acid equivalents)/100 $\mathrm{g}$ dry herbal product, while, on the other hand, the smallest amount was recorded in the roots (sample R4), namely $1.0108 \pm 0.2742 \mathrm{~g}$ (expressed as tannic acid equivalents)/100 $\mathrm{g}$ dry herbal product.

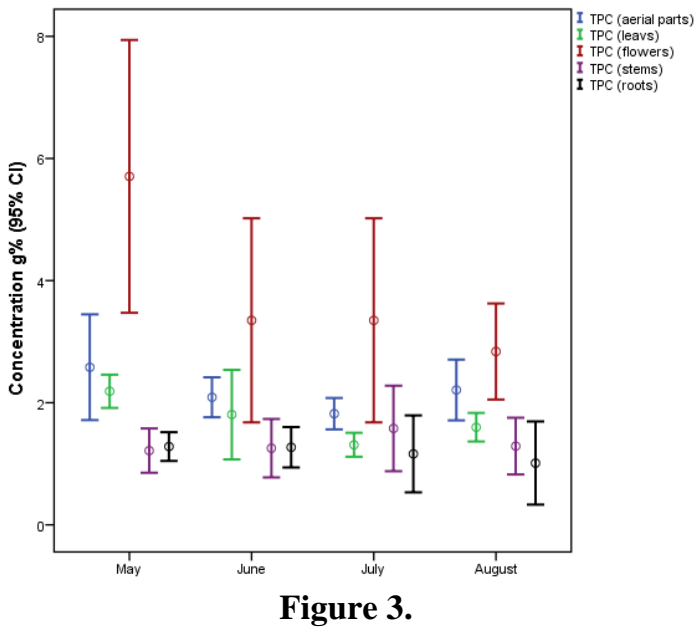

Total polyphenols content (mean) depending on the harvest period, 95\% CI (confidence interval)

Regarding the content of total polyphenols, several results expressed in gallic acid equivalents were reported in the literature.

In the study performed by Jakovljević et al. on the aerial parts of the species Ajuga chamaepitys ssp. chamaepitys, the values $33.70 \pm 0.99$ gallic acid $\mathrm{mg} / \mathrm{g}$ and $57.02 \pm 0.61$ gallic acid $\mathrm{mg} / \mathrm{g}$ were obtained from the methanolic extract, respectively ethyl acetate extract [12]. In the ethanolic extract from the flowers of Ajuga reptans L., Toiu et. al. (2017) obtained $24.11 \pm$ 0.57 gallic acid $\mathrm{mg} / \mathrm{g}$ [21]. Movahhedin et al., in an analysis of the content of total polyphenols on Ajuga chamaecistus subsp. scoparia in which the aerial parts were used, obtained $20.32 \pm 0.39$ gallic acid $\mathrm{mg} / \mathrm{g}$ using the ethanolic extract [15]. Ciocârlan et al., in a phytochemical screening performed on aerial parts of two Ajuga species, Ajuga reptans L. and Ajuga genevensis L., obtained 0.72 gallic acid $\mathrm{g} \%$ for Ajuga reptans L., respectively 0.7154 gallic acid g\% for Ajuga genevensis L. [3]. Also, Toiu et al. (2019) in a comparative phytochemical analysis of extracts from aerial parts where the total polyphenols content was assessed, obtained the highest values $22.59 \pm 0.75$ gallic acid $\mathrm{mg} / \mathrm{g}$ and $26.78 \pm 0.84$ gallic acid mg/g for Ajuga genevensis L. extract in methanol, respectively in ethanol, while the results $19.81 \pm 0.87$ gallic acid $\mathrm{mg} / \mathrm{g}$ and $22.97 \pm 0.48$ gallic acid $\mathrm{mg} / \mathrm{g}$ were obtained for Ajuga reptans L. in methanol, respectively in ethanol [20]. Göger et al. performed a phytochemical screening on the methanolic extract of the species Ajuga orientalis L. collected from the spontaneous flora of Turkey where they obtained 32 gallic acid $\mathrm{mg} / \mathrm{g}$ extract [7]. However, a comparison with data in scientific literature cannot be made because our results are expressed in tannic acid equivalents. 


\section{Conclusions}

The results obtained from all four batches of analysis were higher in the flowers from sample 1 (May 2019), with $7.1501 \mathrm{~g}$ flavonoid content (expressed as rutin equivalents)/100 g dry herbal product and $1.5751 \mathrm{~g}$ phenolic acids content (expressed as chlorogenic acid equivalents)/100 g dry herbal product, respectively $5.706 \mathrm{~g}$ total phenolic content (expressed as tannic acid equivalents $/ 100 \mathrm{~g}$ dry herbal product. Thus, the optimal harvesting interval is in May. On the other hand, the smallest amount was recorded in the root, where no flavonoid content was detected.

The spontaneous flora offers us a multitude of possibilities for exploration and valorisation through research, this species being a scientifically proven source of bioactive compounds. According to the results obtained, it has been shown that Ajuga chamaepitys (L.) Schreb., from spontaneous flora, possesses notable amounts of chemical constituents, which makes us take into account the importance of this plant from a therapeutic point of view. Our purpose being to highlight some preliminary data and considering that the results were promising in terms of the future analysis of the Ajuga chamaepitys (L.) Schreb species, it can be safely presumed that similar studies can be continued using other types of solvents as well as optimized extraction methods.

\section{Acknowledgement}

This work was financially supported by Doctoral degree contract no. 26173/1.10.2018, "Carol Davila" University of Medicine and Pharmacy, Romania.

\section{Conflict of interest}

The authors declare no conflict of interest.

\section{References}

1. Boneva IM, Mikhova BP, Malakov PY, Papanov GY, Duddeck H, Spassov SL, Neo-Clerodane diterpenoids from Ajuga chamaepitys. Phytochemistry, 1990; 29(9): 2931-2933.

2. Camps F, Coll J, Dargallo O, Neo-clerodane diterpenoids from Ajuga chamaepitys. Phytochemistry, 1984; 23(11): 2577-2579.

3. Ciocârlan N, Aprotosoaie AC, Ghendov V, Miron A, Biological and phytochemical studies performed on Ajuga reptans L. and Ajuga genevensis L. (Lamiaceae). Journal of Botany, 2016; VIII(2): 13, (available in Romanian).

4. Ciocârlan V, The illustrated flora of Romania, Pteridophyta et Spermatophyta, Ceres Publishing House, Bucharest, 2009; 640-644, (available in Romanian).

5. Delazar A, Delnavazi MR, Yassa N, Parkhideh S, Delazar N, Nahar L, Sarker SD, Essential oil composition and isolation of free radical-scavenging phenolic glycosides from the aerial parts of Ajuga chamaepitys growing in Iran. Rev Bras Farmacogn., 2012; 22(2): 299-305.
6. Dönmez Ş, Önal F, Germination ability and biochemical properties of Ajuga chamaepitys subsp. Chia var. Chia and Ajuga orientalis cultivated in climatic conditions in Lake District, Turkey. Appl Ecol Environ Res., 2019; 17(2): 3837-3848.

7. Göger F, Köse YB, Göger G, Demirci F, Phytochemical characterization of phenolics by LC-MS/MS and biological evaluation of Ajuga orientalis from Turkey. Bangladesh J Pharmacol., 2015; 10: 639-644.

8. Hernandez A, Pascual C, Sanz J, Rodriguez B, Diterpenoids from Ajuga chamaepitys: two neoclerodane derivatives. Phytochemistry, 1982; 21(12): 2909-2911.

9. Honda G, Yesilada E, Tabata M, Sezik E, Fujita T, Takeda Y, Takaishi Y, Tanaka T, Traditional medicine in Turkey VI. Folk medicine in west Anatolia: Afyon, Kutahya, Denizli, Mugla, Aydin provinces. $J$ Ethnopharmacol., 1996; 53: 75-87.

10. Israili Z, Lyoussi B, Ethnopharmacology of the plants of genus Ajuga. Pak J Pharm Sci., 2009; 22(4): 425-462.

11. Jaffal SM, Abbas MA, Alsalem M, Al-Najjar BO, Evidence for the involvement of opioid receptor in Ajuga chamaepitys action in chemical and thermal models of pain in BALB/c mice. Med Chem Res., 2019; 28: 992-999.

12. Jakovljević DZ, Vasić SM, Stanković MS, Čomić LR, Topuzović MD, Secondary metabolyte content and in vitro biological effects of Ajuga chamaepitys (L.) Schreb. subsp. chamaepitys. Arch Biol Sci., 2015; 67(4): 1195-1202.

13. Khatteli A, Benabderrahim MA, Triki T, Guasmi F, Aroma volatiles, phenolic profile and hypoglycaemic activity of Ajuga iva L. Food Biosci., 2020; 36(2): 100578: 1-7.

14. Luță EA, Ghica M, Costea T, Gîrd CE, Phytosociological study and its influence on the biosynthesis of active compounds of two medicinal plants Mentha piperita L. and Melissa officinalis L., Farmacia, 2020; 68(5): 919-924.

15. Movahhedin N, Zengin G, Bahadori MB, Sarikurkcu C, Bahadori S, Dinparast L, Ajuga chamaecistus subsp. scoparia (Boiss.) Rech.f.: A new source of phytochemicals for antidiabetic, skin-care, and neuroprotective uses. Ind Crops Prod., 2016; 94: 89-96.

16. Orhan I, Deliorman-Orhan D, Özçelik B, Antiviral activity and cytotoxicity of the lipophilic extracts of various edible plants and their fatty acids. Food Chem., 2009; 115(2): 701-705.

17. Săvulescu T, Romanian flora, vol. VIII, Romanian Academy Publishing House, 1961: 150-300, (available in Romanian).

18. Singleton VL, Rosi JA, Colorimetry of total polyphenol with phosphomolybdic - phosphotungstic acid reagents. Am J Enol Vitic., 1965; 37: 144-158.

19. Taha-Salaime L, Davidovich-Rikanati R, Sadeh A, Abu-Nassar J, Marzouk-Kheredin S, Yahyaa Y, Ibdah M, Ghanim M, Lewinsohn E, Inbar M, Aly R, Phytoecdysteroid and Clerodane Content in Three Wild Ajuga Species in Israel. ACS Omega, 2019; 4(1): 2369-2376.

20. Toiu A, Mocan A, Vlase L, Pârvu AE, Vodnar DC, Gheldiu AM, Moldovan C, Oniga I, Comparative 
phytochemical profile, antioxidant, antimicrobial and in vivo anti-inflammatory activity of different extracts of traditionally used Romanian Ajuga genevensis L. and $A$. reptans L. (Lamiaceae). Molecules, 2019; 24(8): 1597: 1-21.

21. Toiu A, Vlase L, Gheldiu AM, Vodnar D, Oniga I, Evaluation of the antioxidant and antibacterial potential of bioactive compounds from Ajuga reptans extract. Farmacia, 2017, 65(3): 351-355.

22. Topçu G, Kokdil G, Turkmen Z, Voelter W, Adou E, Kingston DGI, A New Clerodane Diterpene and Other Constituents from Ajuga chamaepitys ssp. laevigata. Z Naturforsch C J Biosci., 2004; 59b: 584-588.

23. Turkoglu S, Turkoglu I, Kahyaoglu M, Celık S, Determination of antimicrobial and antioxidant activities of Turkish endemic Ajuga chamaepitys (L.) Schreber subsp. euphratica P.H. Davis (Lamiaceae). J Med Plants Res., 2010; 4(13): 1260-1268.

24. Ulukanli Z, Ulukanli S, Ozbay H, Ilcim A, Tuzcu M, Antimicrobial Activities of Some Plants from the Eastern Anatolia Region of Turkey. Pharm Biol., 2005; 43(4): 334-339.

25. Venditti A, Frezza C, Maggi F, Lupidi G, Bramucci M, Quassinti L, Giuliani C, Cianfaglione K, Papa F, Serafini M, Bianco A, Phytochemistry, micromorphology and bioactivities of Ajuga chamaepitys (L.) Schreb. (Lamiaceae, Ajugoideae): Two new harpagide derivatives and an unusual iridoid glycosides pattern. Fitoterapia, 2016; 113: 35-43.

26. Yilmaz B, Chemical constituents of Ajuga chamaepitys (L.) Schreb growing in Turkey by GC-MS method. Int J Pharmacol., 2019; 6(3): 108-112.

27. $* * *$ www.meteoromania.ro. 